\title{
Kualitas Tampilan Vulva dan Tanda-Tanda Berahi pada Kambing Peranakan Etawah yang Diberi Ekstrak Buah Parijoto (Medinilla speciosa)
}

\author{
D. Wijayanti*, F. Ardigurnita \\ *Program Studi Peternakan, Fakultas Pertanian, Universitas Perjuangan Tasikmalaya, \\ Tasikmalaya, Indonesia 57126
}

\begin{abstract}
ABSTRAK
Tujuan dari penelitian ini adalah untuk melihat tampilan kondisi vulva dan tanda-tanda berahi pada kambing Peranakan Etawah yang diberi ekstrak buah Parijoto (Medinilla speciosa). Materi yang digunakan 16 ekor kambing Peranakan Etawah betina umur 1,5-2 tahun dengan bobot badan $80 \pm 0,57 \mathrm{~kg}$. Parameter yang diambil yaitu panjang vulva $(\mathrm{cm})$, lebar vulva $(\mathrm{cm})$, sekreta lendir (skor 1 sampai skor 3), warna vulva (warna putih, merah muda dan merah), suhu vulva $\left({ }^{\circ} \mathrm{C}\right.$ ) dan tanda-tanda berahi. Rancangan penelitian yang digunakan yaitu Rancangan Acak Lengkap, 4 perlakuan dan 4 ulangan ( 0 mg/ekor/bb, 150 $\mathrm{mg} / \mathrm{ekor} / \mathrm{bb}, 200 \mathrm{mg} / \mathrm{ekor} / \mathrm{bb}$ dan $250 \mathrm{mg} / \mathrm{ekor} / \mathrm{bb}$ ). Hasil yang didapat yaitu kualitas tampilan vulva dari panjang dan lebar vulva tidak berbeda nyata $(\mathrm{P}>0,05)$ semua perlakuan sampai hari ke-21 pemberian ekstrak buah Parijoto hingga dosis 250 $\mathrm{mg} / \mathrm{ekor} / \mathrm{bb}$ masing-masing adalah $3,37 \pm 0,63 \mathrm{~cm}$ dan $1,25 \pm 0,25 \mathrm{~cm}$. Sekreta lendir, warna vulva dan suhu vulva pada hari ke21 pemberian ekstrak buah Parijoto dengan dosis $250 \mathrm{mg} / \mathrm{ekor} / \mathrm{bb}$ menunjukkan sekreta lendir bening dalam jumlah banyak $(2,75 \pm 0,50)$, vulva berwarna merah muda dengan suhu $38^{\circ} \mathrm{C}$ yang diikuti dengan munculnya tanda-tanda berahi untuk bersedia dinaiki pejantan mengalami kenaikan hingga 4 kali pada dosis $250 \mathrm{mg} / \mathrm{ekor} / \mathrm{bb}$. Kesimpulannya pemberian ekstrak buah Parijoto sampai level dosis $250 \mathrm{mg} / \mathrm{ekor} / \mathrm{bb}$ dapat meningkatkan kualitas tampilan vulva dan betina bersedia dinaiki pejantan.
\end{abstract}

Kata kunci: Buah Parijoto, Kambing peranakan etawah, Estrus, Vulva

\section{The Quality of Vulva Appearance and Estrus Signs in Etawah Crossbred Goats Given with Parijoto Fruits Extract (Medinilla speciosa)}

\begin{abstract}
The study aimed to see the appearance of vulvar conditions and the signs of the Etawah Crossbreed goat which was given Parijoto fruit extract (Medinilla speciosa). The material used 16 female Etawah Crossbreed goat aged 1.5-2 years with a bodyweight of $80 \pm 0.57 \mathrm{~kg}$. The parameters were taken such as long vulva (cm), Width vulva (cm), Sekreta mucus (score 1 to 3 scores), Color vulva (color white, pink and red), temperature vulva $\left({ }^{\circ} \mathrm{C}\right)$ and signs of the sex. The research was used complete random design, 4 treatment and 4 Deuteronomy $(0 \mathrm{mg} / \mathrm{head} / \mathrm{bb}, 150 \mathrm{mg} / \mathrm{head} / \mathrm{bb}, 200 \mathrm{mg} / \mathrm{head} / \mathrm{bb}$ and 250 $\mathrm{mg} / \mathrm{head} / \mathrm{bb}$ ). The results obtained were the display quality vulva of the length and width of the vulva was no different from the real $(P>0.05)$ all treatment until the 21st day administering the fruit of Parijoto extract up to a dose $250 \mathrm{mg} / \mathrm{head} / \mathrm{bb}$ each was $3.37 \pm 0.63 \mathrm{~cm}$ and $1.25 \pm 0.25 \mathrm{~cm}$. Secreta slime, vulva color On the 21 st day of administering Parijoto fruit with a dose of $250 \mathrm{mg} / \mathrm{head} / \mathrm{bb}$ shows the amount of clear mucus in the number $(2.75 \pm 0.50)$, a pink vulva with a temperature of $38^{\circ} \mathrm{C}$ followed by the emergence of the signs of the sex to be ridden males have an increase up to 4 times at a dose of $250 \mathrm{mg} / \mathrm{head} / \mathrm{bb}$. In conclusion, the introduction of Parijoto fruit extract to a dose level of $250 \mathrm{mg} / \mathrm{head} / \mathrm{bb}$ can improve the display quality of vulva and females willing to climb the stud.
\end{abstract}

Keywords: Parijoto fruit, Etawah crossbreed goat, Estrus, Vulva

\section{PENDAHULUAN}

Performa reproduksi ternak merupakan salah satu yang dapat dijadikan patokan ternak dikatakan memiliki produktivitas yang tinggi atau rendah. Faktor yang mempengaruhi reproduksi adalah kualitas berahi dari ternak itu sendiri. Kambing peranakan etawah (PE) adalah salah satu ternak yang memiliki keunggulan dalam menghasilkan susu dan memiliki lama siklus berahi yang relatif singkat 20-23 hari. Kambing betina sata berahi dapat dilihat dari tingkah lakunya dan tampilan organ kelamin luar seperti vulva mengalami pembekakan, merah, berlendir, hangat, ekor digoyanggoyangkan, mengembik, nafsu makan menurun, kadar estrogen naik, progesterone turun dan bersedia untuk dinaiki pejantan. Umumnya kambing betina pada saat berahi akan mengekspresikan tanda-tanda yang khas,

*Penulis Korespondensi: Dwi Wijayanti

Alamat: Jl. Peta No. 177, Kahuripan, Tawang, Tasikmalaya, Jawa Barat

Email: wijayantidwi12@gmail.com diantaranya organ kelami akan kelihatan membengkak, memerah, lembab, ekor digoyang - goyangkan, sering terdiam tak bergerak dan mengembik. Hal ini sesuai dengan pendapat Anggriawan et al. (2017), perubahan perilaku hewan selama estrus yaitu termasuk vulva sedikit bengkak, keputihan, vulva memerah, gerakan ekor dan kemauan untuk dinaiki pejanten. Tanda-tanda ini secara fisiologis dipengaruhi oleh hormon estrogen dan sangat berkaitan dengan kesuburan. Permasalahan pada kondisi peternakan kambing PE sekarang yaitu kambing PE sering mengalami silent heat, terutama indukan pasca beranak sering mengalami adanya silent heat. Silent heat adalah gangguan reproduksi yang ternak mengalami berahi namun tidak menunjukkan gejalan yang terlihat. Penyebab lain dalam penurunan reproduksi kambing $\mathrm{PE}$ adalah kemampuan peternak dalam mendeteksi tanda-tanda berahi yang muncul. Hal ini karerna kadar estrogen dalam darah relaltif rendah. Menurut Widayati et al. (2018), kadar estrogen mengalami kenaikan pada fase estrus dan mengalami 
penurunan 3-4 hari setelah estrus. Ketika hewan dalam fase estrus, mereka menjadi gelisah dan kondisi ini terkait erat dengan tingkat kortisol. Rasad dan Setiawan (2017) menyatakan bahwa selama fase estrus, estrogen akan meningkat dengan diikuti peningkatan suhu vagina dan $\mathrm{pH}$.

Tindakan yang umumnya dilakukan dalam mengatasi permasalahan ini adalah dengan melakukan penyutikan dengan hormon estrogen. Hormon estrogen berfungsi merangsang berahi, merangsang timbulnya sifat-sifat kelamin sekunder, mempertahankan sistem saluran ambing betina dan pertumbuhan ambing (Wodzicka-Tomaszewska et al., 1991). Metode pemberian hormon ini disebut dengan hormone replacement theraphy. Kambing yang diberikan suntikan estrogen dapat menunjukkan tanda-tanda berahi seperti mengeluarkan lendir banyak, mengembik, bersedia dinaiki pejantan (Dogra et al., 2017). Pemberian hormon dapat meningkatkan kadar estrogen namun memiliki kelemahan jangka panjang yaitu akan meningkatkan resiko penyakit endometrium. Penggunaan hormon seperti PGF2 $\alpha$ secara terus menerus mengganggu sistem pada endometrium (Radi, 2005). Perlu ada alternatif lain dalam menangani kadar hormon estrogen yang rendah pada ternak dengan menggunkan bahan yang lebih aman dan ramah lingkungan. Tanaman herbal adalah tanaman yang alami yang mengandung senyawa sekunder berkhasiat dalam mengatasi berbagai penyakit.

Parijoto adalah salah satu tanaman herbal yang berasal dari daerah Muria, Kudus, Jawa Tengah. Buah Parijoto salah satu bagian dari tanaman Parijoto yang dipercaya oleh masyarakat dapat mengobati berbagai penyakit salah satunya yaitu untuk meningkatkan fertilitas. Kepercayaan masyarakat bahwa buah Parijoto dapat meningkatkan kesuburan. Kandungan dari buah dan daun Parijoto yaitu saponin, flavonoid, tannin, antioksidan, terpenoid dan betakarotein (Wijayanti and Ardigurnita, 2018). Buah Parijoto juga mengandung fitoestrogen yaitu estrogen dari luar tubuh yang berasal dari tumbuhan. Beberapa kelompok fitoestrogen yaitu; isoflavon, lignan, kumestan, triterpen, glikosida, dan senyawa lain yang berefek estrogenik, seperti flavones, chalconcs, diterpenoids, triterpenoids, coumarins dan acyclics (Paper et al., 2018). Fitoestrogen bekerja pada reseptor estrogen memberikan keuntungan sebagai pengganti estrogen. Mekanisme kerja dari isoflavon sebagai bahan fitoestrogen yang mampu memberikan effek estrogenic adalah isoflavon yang mirip dengan senyawa $17-\beta$ estradiol berikatan dengan reseptor estrogen (ER $\alpha$ ) yang terdapat di membran nukleus, sehingga mengaktivasi elemen respon estrogen disisi dalam membran nukleus (Lusiana et al., 2017). Menurut penelitian (Lusiana et al., 2017), pemberian buah kurma sebanyak 1820 mg/ekor/bb dapat meningkatkan hormon estrogen pada mencit. Mekanisme kerja ekstrak buah kurma sebagai salah satu jenis fitoestrogen untuk sinkronisasi siklus estrus secara langsung. Mekanisme secara langsung yaitu fitoestrogen langsung berikatan dengan reseptor estrogen dan mempengaruhi transkripsi gen, sehingga dapat menimbulkan efek seperti estrogen (efek estrogenic). Selain itu menurut penelitian Herdis (2011) bahwa kualitas estrus domba dapat dievaluasi melalui pengamatan vulva merah, basah dan domba betina diam saat dinaiki hewan lain. Sehingga penelitian ini bertujuan untuk mengetahui kualitas tampilan vulva dan tanda-tanda berahi kambing PE yang diberi ekstrak buah Parijoto.

\section{MATERI DAN METODE}

Materi yang digunakan yaitu 16 ekor kambing betina PE umur 1,5-2 tahun dengan bobot badan $80 \pm 0,57 \mathrm{~kg}$. semua kambing perlakuan diberi pakan $2 \mathrm{x}$ sehari.

\section{Ekstraksi Buah Parijoto}

Buah Parijoto didapatkan dari muria Kudus. Dua belas kilo buah Parijoto segar dibersihan dari kotoran dengan mencuci pada air mengalir kemudian dikeringkan dengan suhu $40^{\circ} \mathrm{C}$ selama 24 jam (Sa'Adah et al., 2017; Tussanti and Johan, 2014). Simplisia (sampel kering buah Parijoto) yang sudah dikering dimaserasi dengan etanol $96 \%$ dengan perbandingan 1:10, setiap 3 hari sekali dengan $2 x$ ulangan disaring kemudian diambil filtratnya (Geraldi dan Hastuti, 2018). Hasil filtrate dievaporasi dengan suhu $80^{\circ} \mathrm{C}$ untuk didapatkan ekstrak kental. Hasil ekstraksi disimpan dalam desikator.

\section{Warna Vulva}

Warna mukosa dikategorikan merah dengan skor 3, merah muda dengan skor 2, dan merah muda kepucatan skor 1 (Nurfitriani and Setiawan, 2015; Leigh et al., 2010).

\section{Pengukuran Panjang, Lebar dan Suhu Vagina}

Panjang $(\mathrm{cm})$ dan lebar $(\mathrm{cm})$ vulva ditentukan dari jarak antara komisura dorsalis dan komisura ventralis vulva (Leigh et al., 2010), dengan menggunakan jangka sorong. Suhu vagina diukur dengan menggunakan thermometer $\left({ }^{\circ} \mathrm{C}\right)$. Pengukuran panjang, lebar dan suhu vagina dilakukan pada hari ke-1, ke-7, ke-14 dan ke-21 dilakukan pada pagi hari sebelum pemberian pakan, hal ini supaya kambing masih belum terpengaruh oleh suhu lingkungan dan pakan.

\section{Sekreta Lendir}

Sekreta lendir vagina dikategorikan sebagai berikut: skor 3 (bila sekreta bersifat viscous, bening mengantung atau membasahi sekitar vulva), skor 2 (jumlah sekreta lendir sedikit, sekitar vulva tidak kering sedikit basah), skor 1 (jika tidak ada sekreta yang terlihat) (Nurfitriani and Setiawan, 2015; Leigh et al., 2010).

\section{Tanda-Tanda Berahi}

Tanda-tanda berahi yang diamati yaitu jumlah 
intensitas betina mau untuk dinaiki oleh pejantan dan mengembik. Pejantan pemancing yang digunakan harus memiliki Body Conditional Score (BCS) yang bagus dan kondisi sehat baik reproduksi ataupun badannya (Dogra et al., 2017; Herdis, 2011).

\section{Analisis Data}

Data dianalisis menggunkan ANOVA dengan uji lanjut jika berbeda nyata $(\mathrm{P}<0.05)$ yaitu menggunakan uji Duncan dengan menggunakan aplikasi SPSS.

\section{HASIL DAN PEMBAHASAN}

\section{Warna Vulva}

Warna vulva pada ternak menggambarkan perubahan secara fisik organ luar saat perubahan siklus estrus ternak. Hasil analisis yang didapat dari perubahan warna vulva pada hari ke-1 (Tabel 1) pemberian ekstrak buah Parijoto, kambing perlakuan tidak berbeda nyata $(\mathrm{P}>0,05)$ dengan nilai yang sama yaitu $1,25 \pm 0,50$. Hal ini menunjukkan bahwa efek pemberian ekstrak buah Parijoto belum memberikan efek yang berarti pada kondisi warna vulva kambing perlakuan karena baru diberikan 1 hari. Hari ke-7 (Tabel 2) dan ke-14 (Tabel 3) pemberian ekstrak buah Parijoto kambing antar perlakuan tidak berbeda nyata. Pemberian ekstrak buah Parijoto $200 \mathrm{mg} / \mathrm{ekor} / \mathrm{bb}$ memiliki efek menaikan nilai warna vulva lebih cepat dibandingkan dengan perlakuan 0,150 dan 250

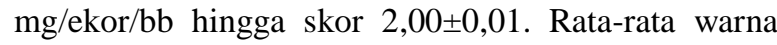
vulva dengan skor 2 hingga hari ke-14 menandakan bahwa warna vulva sudah merah muda. Vulva hewan yang mengalami perubahan merah muda hingga merah menandakan hewan sedang berada pada fase estrus. Perubahan fisiologi yang terjadi selama siklus estrus adalah pemilihan folikel dominan, perkembangan folikuler, pelepasan oosit, tingkat produksi progesteron dan pembentukan corpus luteum (Yoon, 2012). Kondisi fisik yang dialami hewan yang sedang berahi yaitu warna vulva merah muda hingga merah, bengkak dan berlendir (Widiyono et al., 2012). Kandungan flavonoid pada buah Parijoto termasuk dalam senyawa isoflavon yang bersifat estrogenik membantu mengaktifkan hormon estrogen. Tanaman yang mengandung senyawa isoflavon juga fitoestrogen dapat menyeimbangkan kadar estrogen dalam tubuh (Wijayanti and Ardigurnita, 2018).

Pemberian ekstrak buah Parijoto hari ke-21 (Tabel 4) pada kambing PE yang diberi ekstrak buah Parijoto dengan dosis level $250 \mathrm{mg} / \mathrm{ekor} / \mathrm{bb}$ dibandingkan dengan perlakuan $0 \mathrm{mg} / \mathrm{ekor} / \mathrm{bb}, 150 \mathrm{mg} / \mathrm{ekor} / \mathrm{bb}$ dan $200 \mathrm{mg} / \mathrm{ekor} / \mathrm{bb}$ menunjukkan perbedaan nyata $(\mathrm{P}<0,05)$. Perubahan warna vulva memiliki skor diatas 2 yang menandakan warna vulva merah muda hampir merah. Kambing yang diberi ekstrak buah Parijoto dengan dosis 250 mg/ekor lebih menunjukkan perubahan warna vulva kemerahan. Fitoestrogen yang ada dalam ekstrak buah Parijoto dapat berikatan langsung dengan reseptor estrogen yang dapat menjadi efek estrogenic ataupun anti estrogenik. Kadar estrogen endogen dalam tubuh yang rendah akan diseimbangkan oleh fitoestrogen, sebaliknya jika kadar estrogen dalam tubuh berlebih maka akan diseimbangkan. Warna merah pada vulva menunjukkan kebengkakan vulva yang sedang estrus. Kondisi vulva akan saling berkaitan dengan kenaikan kadar estrogen saat estrus (Widiyono et al., 2012). Vulva yang bengkak diakibatkan karena adanya ketengangan dari syaraf otot vulva yang disebabkan karena kadar estrogen yang tinggi. Kondisi vulva saat estrus akan berwarna kemerahan, vulva bengkak dan mengeluarkan lendir banyak (Ridlo et al., 2018). Keadaan pada pengamatan ini kambing betina sudah telihat mulai masuk pada tahap awal estrus sehingga kecenderungannya akan mengalami kenaikan kadar estrogen dalam darahnya. Menurut Frandson et al. (2003) estradiol merangsang penebalan dinding vagina, peningkatan vaskularisasi menyebabkan alat kelamin bagian luar mengalami pembengkakan dan berwarna kemerahan, serta peningkatan sekresi lendir atau mukosa vagina sehingga dijumpai adanya lendir menggantung di vulva atau menempel di sekitarnya. Perubahan FSH dan estrogen dalam darah menyebabkan perubahan fisiologis tubuh ternak yang dimanifestasikan pada perubahan fisik berupa pembengkakan vulva maupun vulva berwarna merah (Nurfitriani and Setiawan, 2015).

\section{Panjang dan Lebar Vulva}

Ukuran vulva dapat digunakan dalam memperhitungkan kondisi siklus berahi dari kambing. Kebengkakan vulva dapat dilihat dari panjang dan lebar vulva yang menandakan hewan sedang mengalami berahi. Hasil analisis panjang vulva kambing PE tidak berbeda nyata $(\mathrm{P}>0,05)$ antar perlakuan pada hari-1, hari ke-7, hari ke-14 dan hari ke-21 dari semua perlakuan. Pemberian ekstrak buah Parijoto pada hari ke-1 dan hari ke-7 mengalami penurunan panjang vulva. Hal ini disebabkan kambing sedang tidak berada fase estrus melainkan fase awal proestrus dan kadar

Tabel 1. Profil Estrus Kambing Peranakan Etawah pada Hari ke-1 Pemberian Ekstrak Buah Parijoto

\begin{tabular}{ccccccc}
\hline \hline $\begin{array}{c}\text { Perlakuan } \\
\text { Perlakuan } \\
(\mathrm{mg} / \text { /ekor/bb) }\end{array}$ & $\begin{array}{c}\text { Panjang } \\
\text { vulva }(\mathrm{cm})\end{array}$ & $\begin{array}{c}\text { Lebar } \\
\text { vulva }(\mathrm{cm})\end{array}$ & $\begin{array}{c}\text { Sekreta } \\
\text { lendir }\end{array}$ & $\begin{array}{c}\text { Warna } \\
\text { vulva }\end{array}$ & $\begin{array}{c}\text { Tanda-tanda } \\
\text { berahi }\end{array}$ & $\begin{array}{c}\text { Suhu vulva } \\
\left({ }^{\circ} \mathrm{C}\right)\end{array}$ \\
\hline 0 & $3,05 \pm 0,99$ & $2,00 \pm 1,77$ & $1,25 \pm 0,50$ & $1,25 \pm 0,50$ & $1,00 \pm 0,01^{\mathrm{a}}$ & $37,12 \pm 0,25^{\mathrm{a}}$ \\
150 & $3,75 \pm 0,98$ & $2,07 \pm 0,80$ & $1,00 \pm 0,01$ & $1,25 \pm 0,50$ & $1,00 \pm 0,01^{\mathrm{a}}$ & $38,00 \pm 0,01^{\mathrm{b}}$ \\
200 & $3,17 \pm 0,55$ & $1,65 \pm 0,44$ & $1,00 \pm 0,01$ & $1,25 \pm 0,50$ & $1,50 \pm 0,50^{\text {ab }}$ & $38,25 \pm 0,64^{\mathrm{b}}$ \\
250 & $3,10 \pm 0,66$ & $2,10 \pm 1,16$ & $1,25 \pm 0,50$ & $1,25 \pm 0,50$ & $1,75 \pm 0,57^{\text {ab }}$ & $37,62 \pm 0,75^{\mathrm{a}}$ \\
\hline
\end{tabular}

a,b Superskrip yang tidak sama pada baris yang sama menunjukkan berbeda nyata pada taraf signifikansi $95 \%$ 
estrogen masih rendah. Hal ini karena kadar estrogen masih rendah. Defisiensi estrogen menyebabkan vagina kehilangan kolagen, jaringan adiposa, dan kemampuan untuk menahan air, sehingga dinding vagina menyusut (Sugiritama dan Adiputra, 2019). Panjang vulva pada hari ke-14 dan hari ke-21 mengalami kenaikan panjang vulva dari kambing yang diberi ekstrak buah Parijoto dari level dosis $150 \mathrm{mg} / \mathrm{ekor} / \mathrm{bb}$ sampai 250 $\mathrm{mg} / \mathrm{ekor} / \mathrm{bb}$. Ukuran panjang celah vulva yang paling panjang ada pada kambing yang diberi ekstrak buah Parijoto dengan level $250 \mathrm{mg} / \mathrm{ekor} / \mathrm{bb}$ pada perlakuan hari ke-1. Panjang celah vulva domba local yang mengalami estrus yaitu 3,03 $\pm 0,54 \mathrm{~cm}$ (Nurfitriani and Setiawan, 2015). Menurut (Leigh et al., 2010), panjang celah vulva kambing Dwarf di Afrika saat estrus yaitu $1,88 \pm 1,17 \mathrm{~cm}$.

Tingginya estrogen menyebabkan sirkulasi darah meningkat pada alat reproduksi ternak betina, menjadikan tampilan vagina membengkak dan perubahan celah vulva saat ternak estrus. Pembekakan menyebabkan jaringan pembuluh darah bertambah banyak sehingga meningkatkan aliran darah ke saluran reproduksi. Lebar vulva dari semua perlakuan pada hari ke-1, ke-7, ke-14 dan ke-21 tidak berbeda nyata $(\mathrm{P}>0,05)$. Hal ini sependapat dengan (Iskandar and Setiatin 2015), kambing kejobong yang diberi ekstrak hipofisa tidak memberikan perbedaan tampilan berahi diamati dari perubahan vulva. Nilai panjang vulva dan lebar vulva dapat dilihat dengan kebengkakan pada vulva. Sutama (2011) menyatakan bahwa kambing PE terjadi pembengkakan vulva saat berahi. Vulva yang mengalami estrus akan terlihat memerah dan kondisi labia minora mebal. Hal ini karena pembuluh darah bagian servik sampai vulva mengalami ereksi sehingga terjadi pembekakan yang diikuti dengan perubahan warna vulva menjadi kemerahan. Penambahan ekstrak buah Parijoto menyebabkan kenaikan kadar estrogen pada darah. Isoflavon yang ada pada buah Parijoto dapat memberikan efek estrogenic yang menyerupai estrogen dalam tubuh ternak sehingga dapat menaikan kadar estrogen dalam darah. Implikasi klinis isoflavone tergantung pada beberapa faktor termassuk jumlah reseptor yang dapat binding dengan isoflavon, letak reseptor dan konsentrasi estrogen yang mampu bersaing dengan isoflavone (Lusiana et al., 2017).

\section{Suhu Vagina}

Suhu vagina berdasarkan hasil analisis pada hari ke-1 (Tabel 1) berbeda nyata $(\mathrm{P}<0,05)$ kambing yang diberi ekstrak buah Parijoto dengan dosis 150 dan 200 mg/ekor/bb berbeda nyata dengan kambing yang tidak diberi ekstrak buah Parijoto. Tabel 2, suhu vagina antar perlakuan pada hari ke-7 tidak berbeda nyata $(\mathrm{P}>0.05)$. Organ vagina mengalami kenaikan suhu pada kambing yang diberi ekstrak buah Parijoto sampai level 250 mg/ekor/bb. Peningkatan sirkulasi darah saat estrus daerah vagina menyebabkan adanya perubahan suhu pada vagina. Hari ke-14 menunjukkan bahwa ada perbedaan yang nyata antar kambing yang diberi perlakuan ekstrak buah Parijoto. Kambing yang diberi esktrak buah Parijoto memiliki suhu tertinggi yaitu $37.62{ }^{\circ} \mathrm{C}$. Peningkatan suhu vagina diikuti dengan warna vulva pada hari ke-14 yang merah muda kemerahan (Tabel 3). Flavonoid dan antioksidan dalam buah Parijoto memberikan efek aksi hampir sama seperti estrogen. Kambing yang mengalami peningkatan kadar estrogen menyebabkan aliran darah meningkat sehingga menyebabkan vulva membengkak dan suhu vagina meningkat. Pemberian ekstrak buah Parijoto pada hari ke-21 menunjukkan tidak ada perbedaan nyata antar perlakuan pada suhu vagina.

Suhu pada kambing mengalami peningkatan yang diberi eksrak buah Parijoto pada semua level. Suhu tertinggi pada level dosis $150 \mathrm{mg} / \mathrm{ekor} / \mathrm{bb}$ yaitu $38,12 \pm 0,47$. Peningkatan suhu vagina juga diikuti dengan perubahan suhu tubuh pada hewan. Temperatur tubuh kambing peranakan etawah yang sudah disinkronisasi estrus pada kelompok perlakuan 9 hari terlihat naik pada fase puncak estrus (jam ke-75 dan 82) yaitu $39 \pm 0,26{ }^{\circ} \mathrm{C}$ dan $38,7 \pm 0,20{ }^{\circ} \mathrm{C}$ (Ridlo et al., 2018).

Tabel 2. Profil Estrus Kambing Peranakan Etawah pada Hari ke-7 Pemberian Ekstrak Buah Parijoto

\begin{tabular}{ccccccc}
\hline \hline \multirow{2}{*}{$\begin{array}{c}\text { Perlakuan } \\
\text { Perlakuan } \\
(\mathrm{mg} / \mathrm{ekor} / \mathrm{bb})\end{array}$} & $\begin{array}{c}\text { Panjang } \\
\text { vulva }(\mathrm{cm})\end{array}$ & $\begin{array}{c}\text { Lebar } \\
\text { vulva }(\mathrm{cm})\end{array}$ & $\begin{array}{c}\text { Sekreta } \\
\text { lendir }\end{array}$ & $\begin{array}{c}\text { Warna } \\
\text { vulva }\end{array}$ & $\begin{array}{c}\text { Tanda-tanda } \\
\text { berahi }\end{array}$ & Suhu vulva $\left({ }^{\circ} \mathrm{C}\right)$ \\
\hline 0 & $3,50 \pm 1,08$ & $1,35 \pm 0,68$ & $1,00 \pm 0,01$ & $1,75 \pm 0,50$ & $1,00 \pm 0,01$ & $37,87 \pm 0,47$ \\
150 & $3,02 \pm 0,70$ & $1,62 \pm 0,69$ & $1,00 \pm 0,01$ & $1,25 \pm 0,50$ & $1,00 \pm 0,01$ & $36,50 \pm 2,04$ \\
200 & $2,50 \pm 0,77$ & $1,40 \pm 0,37$ & $1,25 \pm 0,50$ & $2,00 \pm 0,01$ & $1,00 \pm 0,50$ & $38,25 \pm 0,95$ \\
250 & $2,50 \pm 0.37$ & $1,35 \pm 0,12$ & $1,25 \pm 0,50$ & $1,50 \pm 0,57$ & $1,00 \pm 0,50$ & $37,75 \pm 0,86$ \\
\hline
\end{tabular}

${ }_{\mathrm{a}, \mathrm{b}}$ Superskrip yang tidak sama pada baris yang sama menunjukkan berbeda nyata pada taraf signifikansi $95 \%$

Tabel 3. Profil Estrus Kambing Peranakan Etawah pada Hari ke-14 Pemberian Ekstrak Buah Parijoto

\begin{tabular}{ccccccc}
\hline \hline \multirow{2}{*}{$\begin{array}{c}\text { Perlakuan } \\
\text { Perlakuan } \\
(\mathrm{mg} / \mathrm{ekor} / \mathrm{bb})\end{array}$} & $\begin{array}{c}\text { Panjang } \\
\text { vulva }(\mathrm{cm})\end{array}$ & $\begin{array}{c}\text { Lebar } \\
\text { vulva }(\mathrm{cm})\end{array}$ & $\begin{array}{c}\text { Sekreta } \\
\text { lendir }\end{array}$ & $\begin{array}{c}\text { Warna } \\
\text { vulva }\end{array}$ & $\begin{array}{c}\text { Tanda-tanda } \\
\text { berahi }\end{array}$ & Suhu vulva $\left({ }^{\circ} \mathrm{C}\right)$ \\
\hline 0 & $2,80 \pm 1,04$ & $1,40 \pm 0,84$ & $1,00 \pm 0,01$ & $2,00 \pm 0,01$ & $1,00 \pm 0,01^{\mathrm{a}}$ & $37,25 \pm 0,95^{\mathrm{ab}}$ \\
150 & $2,58 \pm 0,62$ & $1,72 \pm 0,45$ & $1,25 \pm 0,50$ & $2,00 \pm 0,01$ & $1,50 \pm 0,58^{\mathrm{ab}}$ & $36,25 \pm 0,50^{\mathrm{a}}$ \\
200 & $3,07 \pm 0,57$ & $1,50 \pm 0,33$ & $1,50 \pm 0,57$ & $2,00 \pm 0,01$ & $2,50 \pm 1,29^{\mathrm{b}}$ & $36,62 \pm 1,03^{\mathrm{ab}}$ \\
250 & $3,00 \pm 0,28$ & $1,57 \pm 0,33$ & $1,50 \pm 0,57$ & $2,00 \pm 0,01$ & $2,50 \pm 1,00^{\mathrm{b}}$ & $37,62 \pm 0,62^{\mathrm{b}}$ \\
\hline
\end{tabular}

${ }_{\mathrm{a}, \mathrm{b}}$ Superskrip yang tidak sama pada baris yang sama menunjukkan berbeda nyata pada taraf signifikansi $95 \%$ 
Level dosis $150 \mathrm{mg} / \mathrm{ekor} / \mathrm{bb}$ belum maksimal karena belum diikuti dengan panjang vulva dan warna vulva yang masih berwarna merah muda. Panjang vulva, warna vulva (kemerahan) yang maksimal pada hari ke21 menunjukkan fase estrus pada kambing yang diberi level dosis $250 \mathrm{mg} / \mathrm{ekor} / \mathrm{bb}$ ekstrak buah Parijoto diikuti dengan suhu vagina yaitu $38,00 \pm 0,57^{\circ} \mathrm{C}$. Hormon estrogen tinggi menyebabkan peningkatan aliran darah menuju vagina dan vulva sehingga menyebabkan suhu vulva naik. Ekstrak buah Parijoto dapat meningkatkan hormon estrogen pada kambing yang mengalami penurunan kadar estrogen rendah dengan sifatnya yang estrogenik. Menurut Ratri et al. (2011), suplai darah dalam saluran alat kelamin mengalami peningkatan karena kadar estradiol yang tinggi. Aktivitas-aktivitas sel didaerah vagina juga mengalami peningkatan sehingga didaerah vagina dan vulva berbubah warna menjadi kemerahan dan mengalami pembekakan. Flavonoid, saponin dan betakarotein dalam buah Parijoto merupakan senyawa yang mengandung antioksidan tinggi. Kandungan flavonoid pada buah Parijoto 3,61 \%b/b dan saponin 3,715\%b/b (Wijayanti and Ardigurnita, 2018). Senyawa yang mengandung antioksidan tinggi dapat meningkatkan kesuburan.

\section{Sekreta Lendir}

Kondisi vulva dari suhu, kebengkakan saat mengalami estrus juga diikuti dengan jumlah sekreta ledir. Beradasarkan hasil analisis pemberian ekstrak buah Parijoto pada hari ke-1, hari ke-7 dan hari ke-14 tidak berbeda nyata $(\mathrm{P}>0,05)$. Jumlah sekreta lendir paling banyak terdapat pada kambing yang diberi ekstrak buah Parijoto dengan level $250 \mathrm{mg} / \mathrm{ekor} / \mathrm{bb}$

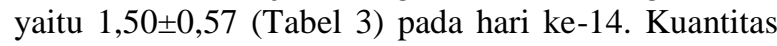
lendir tersebut dapat disebabkan oleh status nutrisi, kuantitas lendir sebagai sifat fisik mempunyai kandungan yang berupa air, protein, lemak, karbohidrat dan mineral (Zaenuri dan Rodiah, 2016). Hari ke-21 (Tabel 4) jumlah sekreta lendir pada kambing yang tidak diberi ekstrak buah Parijoto berbeda nyata $(\mathrm{P}<0,05)$ dengan kambing yang diberi ekstrak buah Parijoto hingga level $250 \mathrm{mg} / \mathrm{ekor} / \mathrm{bb}$.

Sekresi lendir semakin tinggi ketika hewan mencapai masa estrusnya. Kambing yang diberi ekstrak buah Parijoto memiliki jumlah sekreta lendir lebih banyak dibandingkan kambing yang tidak diberi perlakuan. Sekreta lendir yang bening yang membasahi vulva sebagai tanda hewan mengalami estrus. Semakin tinggi level dosis ekstrak buah Parijoto yang diberikan maka semakin tinggi juga sekreta lendir. Buah Parijoto mengandung antioksidan yang berpotensi meningkatkan kesuburan. Antioksidan juga berfungsi sebagai menangkal radikal bebas yang dapat merusak fungsi sistem organ reproduksi dalam menghasilkan hormon estrogen. Antioksidan juga melindungi munculnya stress oksidatif, hal ini karena hormon estrogen yang turun (Sugiritama dan Adiputra, 2019).

\section{Tanda-Tanda Berahi}

Tanda-tanda berahi yang diamati setelah pemberian ekstrak buah Parijoto adalah kemaun betina bersedia untuk dinaiki pejantan. Kambing yang diberi ekstrak buah Parijoto dengan dosis 200 dan 250 mg/ekor/bb berbeda nyata $(\mathrm{P}<0,05)$ dengan kambing yang diberi perlakuan dengan level $150 \mathrm{mg} / \mathrm{ekor} / \mathrm{bb}$ dan kambing yang tidak diberi perlakuan (Tabel 1). Hari ke7 pemberian ekstrak buah Parijoto tidak ada perbedaan yang nyata antarperlakuan (Tabel 2). Tidak ada kambing betina perlakuan yang menerima pejantan pemancing untuk didekati dan dinaiki. Hal ini menunjukkan bahwa kambing PE tidak berada pada fase estrus. Jumlah estrogen dalam tubuh ternak rendah sehingga belum muncul tanda-tanda kambing berahi, diikuti dengan data yang ada yaitu suhu vulva dan sekreta lendir yang masih belum terlihat. Faktor gizi dan status nutrisi ternak dapat mempengaruhi intensitas birahi karena berhubungan dengan hormon hormon reproduksi (Partodihardjo, 1980). Tanda-tanda berahi selain betina bersedia untuk dinaiki adalah nafsu makan menurun. Hormon leptin dapat menghambat nafsu makan dan menurunkan konsumsi makanan. Tandatanda gelisah, nafsu makan turun atau hilang sama sekali, menghampiri pejantan dan tidak lari bila pejantan menungganginya (Saoeni, 2007).

Hari ke-14 pemberian ekstrak buah Parijoto dengan dosis 250 dan $200 \mathrm{mg} / \mathrm{ekor} / \mathrm{bb}$ berbeda nyata $(\mathrm{P}<0,05)$ dengan kambing $\mathrm{PE}$ yang tidak diberikan ekstrak buah Parijoto. Kambing PE yang diberi dosis hingga $250 \mathrm{mg} / \mathrm{ekor} / \mathrm{bb}$ bersedia dinaiki pejantan pemancing hingga 3 kali. Ekstrak buah Parijoto dengan dosis $250 \mathrm{mg}$ /ekor/bb yang diberikan pada kambing PE betina sampai hari ke-21 menunjukkan betina bersedia dinaiki pejantan sampai 4 kali. Kesediaan betina untuk dinaiki pejantan diikuti dengan suhu vulva yang hangat dan warna vulva yang merah muda kemerahan. Penurunan kadar progesteron dan diikuti peningkatan kadar hormon estrogen merupakan tanda awal munculnya berahi. Tingkah laku berahi muncul disebabkan karena follicle stimulating hormone (FSH)

Tabel 4. Profil Estrus Kambing Peranakan Etawah pada Hari ke-21 Pemberian Ekstrak Buah Parijoto

\begin{tabular}{ccccccc}
\hline \hline \multirow{2}{*}{$\begin{array}{c}\text { Perlakuan } \\
\text { Perlakuan } \\
(\mathrm{mg} / \mathrm{ekor} / \mathrm{bb})\end{array}$} & $\begin{array}{c}\text { Panjang } \\
\text { vulva }(\mathrm{cm})\end{array}$ & $\begin{array}{c}\text { Lebar } \\
\text { vulva }(\mathrm{cm})\end{array}$ & $\begin{array}{c}\text { Sekreta } \\
\text { lendir }\end{array}$ & $\begin{array}{c}\text { Warna } \\
\text { vulva }\end{array}$ & $\begin{array}{c}\text { Tanda-tanda } \\
\text { berahi }\end{array}$ & Suhu vulva $\left({ }^{\mathrm{o}} \mathrm{C}\right)$ \\
\hline 0 & $3,12 \pm 0,92$ & $1,25 \pm 0,82$ & $1,25 \pm 0,50^{\mathrm{a}}$ & $2,00 \pm 0,01^{\mathrm{a}}$ & $1,25 \pm 0,50^{\mathrm{a}}$ & $37,50 \pm 0,81$ \\
150 & $2,80 \pm 0,59$ & $1,00 \pm 0,62$ & $2,25 \pm 0,95^{\mathrm{b}}$ & $2,00 \pm 0,01^{\mathrm{a}}$ & $1,25 \pm 0,50^{\mathrm{a}}$ & $38,12 \pm 0,47$ \\
200 & $3,20 \pm 0,43$ & $1,00 \pm 0,45$ & $2,75 \pm 0,50^{\mathrm{b}}$ & $2,00 \pm 0,01^{\mathrm{a}}$ & $2,00 \pm 1,15^{\text {ab }}$ & $37,25 \pm 0,86$ \\
250 & $3,37 \pm 0,63$ & $1,25 \pm 0,25$ & $2,75 \pm 0,50^{\mathrm{b}}$ & $2,75 \pm 0,50^{\mathrm{b}}$ & $3,25 \pm 0,95^{\mathrm{b}}$ & $38,00 \pm 0,57$ \\
\hline
\end{tabular}

Keteragan: *Superskrip yang tidak sama pada baris yang sama menunjukkan berbeda nyata pada taraf signifikansi $95 \%$ 
dan luteinizing hormone (LH) dari hipofise anterior dirangsang oleh peningkatan hormon estrogen (Herdis, 2011). Pemunculan tingkah laku birahi tersebut diawali karena adanya rangsangan dari luar terhadap indera (penglihatan, pendengaran, penciuman dan perasa) yang diterima oleh hipotalamus dan kemudian hipotalamus memerintahkan hipofisa anterior supaya mensekresikan hormon FSH untuk pertumbuhan dan pematangan folikel di ovarium sehingga sel teka dalam ovarium mensekresikan hormon estrogen (Anisa et al., 2017). Kenaikan hormon estrogen akan memberikan signal kepada hipotalamus untuk mensekresikan hormone ACTH sehingga hormon adrenalin tersekresikan. Hormon adrenalin yang tinggi akan menyebabkan tekanan jantung lebih cepat sehingga memberikan signal kepada hipotalamus untuk memeberikan respon berupa perubahan tingkah laku.

Senyawa sekunder dari buah Parijoto yang terdiri dari flavonoid, saponin, betakarotein dan tannin termasuk dalam senyawa isoflavon yang memiliki efek hormonal. Efek hormonal berupa efek estrogenic. Efek fitoestrogen memiliki efek yang berbeda-beda tergantung spesies, umur, jenis kelamin, dosis, cara pemberian dan metabolisme. Tambahan pemberian flavonoid yang termasuk dalam isoflavon dapat berikatan dengan reseptor estrogen yang tidak terikat sehingga kadar estrogen tidak turun. Penambahan ekstrak buah Parijoto dapat berikatan dengan reseptor estrogen endogen sehingga estrogen tetap dalam keadaan normal. Sutama (2007) menyatakan bahwa lama siklus berahi pada kambing adalah 18-24 hari dengan rata-rata 21 hari. Isoflavon mempunyai afinitas terhadap reseptor estrogen meskipun affinitasnya tersebut lebih lemah 1/1000 kali dibandingkan estradiol

\section{KESIMPULAN}

Pemberian ekstrak buah Parijoto sampai level dosis $250 \mathrm{mg} / \mathrm{ekor} / \mathrm{bb}$ dapat meningkatkan kualitas tampilan vulva dan betina bersedia dinaiki pejantan.

\section{UCAPAN TERIMA KASIH}

Ucapan terimakasih kepada Kementrian Riset dan Teknologi telah memberikan hibah penelitian skim PDP tahun 2018 dan P4S Agribisnis As-Salam.

\section{DAFTAR PUSTAKA}

Anggriawan, R.P., S. Utama and H. Eliyani. 2017. The relation of body temperature and vaginal cytology examination in time artificial insemination rate fat-tailed sheep (Ovis aries) in the district Sidoarjo East Java. KnE Life Science 3: 642-649.

Anisa, E., Y. S. Ondho and D. Samsudewa. 2017. Pengaruh body condition score (bcs) berbeda terhadap intensitas birahi sapi induk simmental peranakan ongole (simpo). Jurnal Sain Peternakan Indonesia 12(2): 133-141.

Dogra, P., G. S. Dhaliwal and S Kaswan. 2017. Estrous behaviour, physio-chemical properties and vaginal cytology of cervical mucus in beetal goats during induced. Indian Journal of Animal Reproduction 38(6): 41-44.

Geraldi, E. T. dan E. D. Hastuti. 2018. Formulation of sunscreen cream of Parijoto fruit extract (medinilla speciosa blume) and in vitro spf value test. Jurnal Farmasi Sains dan Komunitas 15(2): 92-98.

Herdis. 2011. Respon estrus domba garut betina pada perlakuan laserpuntur dengan fase reproduksi yang berbeda. Jurnal Sains dan Teknologi Indonesia 13(11): 171-76.

Iskandar. F. and E. T. Setiatin and Sutiyono. 2015. Changes vulva and cervical mucus secretion improvement as indicators in estrus female goats kejobong using the enhanced fertility pituitary extract) pendahuluan kambing kejobong merupakan kambing lokal yang banyak terdapat di kabupaten purbalingga. Agromedia 33(2):28-34.

Leigh, O. O., A. K. Raheem and J. A. Olugbuyiro. 2010. Improving the reproductive efficiency of the goat : vaginal cytology and vulvar biometry as predictors of synchronized estrus / breeding time in west african dwarf goat. Internasional Journal of Morphology 28(3): 923-928.

Lusiana. 2017. Pengaruh fitoestrogen daging buah kurma ruthab (phoenix dactylifera 1.) Terhadap sinkronisasi siklus estrus mencit (mus musculus 1.) Betina. Klorofil 1(1): 24-31.

Nurfitriani, I. and R. Setiawan. 2015. Karakteristik vulva dan sitologi sitologi sel mucus dari vagina fase estrus pada domba lokal. Student e-Journal 4(3): 1-10.

Partodihardjo, S. 1980. Ilmu Reproduksi Hewan. Mutiara, Jakarta.

Radi, Z.A. 2005. Endometritis and cystic endometrial hyperplasia in a goat. J Vet Diagn Invest 17:393-395.

Rasad, S.D. and R. Setiawan, 2017. Cytological characteristics of mucose cell and vaginal temperature and $\mathrm{pH}$ during estrous cycle in local sheep. Animal Production 19: 21-27.

Ridlo, M. R., R. Ummami, N. Wanda and Y. Dalimunthe. 2018. Profil vulva dan suhu tubuh kambing peranakan etawa pada sinkronisasi estrus menggunakan medroxy progesterone acetate dan suplementasi zinc (zn). Jurnal Nasional Teknologi Terapan 2(2): 198-211.

Sa'Adah, N.N., A. P. D. Nurhayati and K. I. Purwani. 2018. Antihyperlipidemic and Anti-Obesity Effects of the Methanolic Extract of Parijoto (Medinilla Speciosa). AIP Conference Proceedings Inventing Prosperous Future through Biological Research and Tropical 
Biodiversity Management. Solo. pp. 020046-1020046-8.

Sa'Adah, N.N., K.I. Purwani, A.P.D. Nurhayati and N. Maulidina Ashuri. 2017. Analysis of Lipid Profile and Atherogenic Index in Hyperlipidemic Rat (Rattus Norvegicus Berkenhout, 1769) That given the Methanolic Extract of Parijoto (Medinilla Speciosa). AIP Conference Proceeding of International Biology Conference. Solo. pp. 020031-1 - 020031-10.

Saoeni, R. 2007. The Application of synchronization methods using prostaglandin f $2 \square$,by intra vaginal sponges (ivs) and intra muscular (im) to improve reproductive performance of thintailed ewe lambs. Animal Production 9(3): 129-134.

Sugiritama, I.W. dan I.N. Adiputra. 2019. Potensi antosianin dalam manajemen menopause. Jurnal Kesehatan Andalas 8(1): 158-166.

Sutama, I.K. 2011. Inovasi Teknologi Reproduksi mendukung pengembangan kambing perah lokal. Pengembangan Inovasi Pertanian 4(3): 231-46.

Tussanti, I. dan A. Johan. 2014. Sitotoksisitas in vitro ekstrak etanolik buah Parijoto (medinilla speciosa, reinw. ex bl.) terhadap sel kanker payudara t47d. Jurnal Gizi Indonesia 2(2): 5358.

Widayati, D.T., P.I. Sitaresmi, S. Bintara and B.P. Widyobroto. 2018. Estrus detection through vaginal $\mathrm{pH}$ in saanen etawah crossbreed goats. Pakistan Journal of Biological Sciences 21 (8): 383-386.

Widiyono, I., P.P. Putro, Sarmin, P. Astuti, C. M. Airin. 2012. Kadar Estradiol dan progesteron serum, tampilan vulva dan sitologi apus vagina kambing bligon selama siklus birahi. Jurnal Veteriner 12(4): 263-68.

Wijayanti, D. and F. Ardigurnita. 2018. Potential of Parijoto (medinilla speciosa) fruits and leaves in male fertility. Animal Production 20(32): 81-86.

Yoon, M. 2012. The estrous cycle and induction of ovulation in mares. Journal of Animal Science and Technology 54(3): 165-174.

Zaenuri, L. A. dan Rodiah. 2016. Efektifitas Progesteron Kering dan Basah Sebagai Perangsang Birahi Ternak Kambing. Jurnal Ilmu dan Teknologi Peternakan Indonesia 2(1): 129-133. 